\title{
The Effects Of Business Strategy On The Association Between R\&D Expenditure And Future Firm Performance
}

\author{
Anjung Chung, Director, Korea Printed Electronics Association, South Korea
}

Manseek Choi, Hanyang University, South Korea

\begin{abstract}
Research and Development $(R \& D)$ expenditure is one of the most essential factors for firm's sustainable growth. Business strategy describes long-term business planning of a company, and chosen business strategy will have a significant impact on the financial status and performance of a firm. This study examines whether the business strategy affects the association between $R \& D$ and firm performance, defined as earnings persistence, earnings growth, and firm value. Like Jermias (2008), product differentiation and cost leadership strategies are classified by the cluster analysis using three ratios: $R \& D$ intensity, asset turnover, and profit margin ratio.

Our findings are as follows. (1) the effect of $R \& D$ expenditure on earnings persistence according to the business strategy appeared to be almost insignificant. (2) the effects of $R \& D$ expenditure on earnings growth up to three consecutive years are stronger in firms with product differentiation strategy than in firms with cost leadership strategy. These results indicate that $R \& D$ are more important and have greater impacts on future performance for product differentiation firms than for cost leadership firms. (3) $R \& D$ expenditure of product differentiation firms are more closely related to the firm value than $R \& D$ expenditure of cost leadership firms. The results of this study will be useful to practitioners when they are making R\&D-related decisions based on their business planning. Also, this study provides useful empirical results to financial analysts and accounting academics when they are analyzing profitability and firm value.
\end{abstract}

Keywords: R\&D; Business Strategy; Earnings Persistence; Earnings Growth; Firm Value

\section{INTRODUCTION}

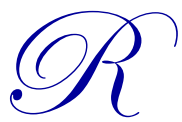

esearch and Development expenditure is one of the most important investment for the continuous growth of a firm by improving the quality of products and services. From the perspective of shareholder value maximization, the ultimate goal of $R \& D$ investment is to maximize corporate value through enhancing and maintaining profitability. In addition, continuous effort for the R\&D is essential for the survival of a firm in the competitive market. It implies that choosing business strategy for achieving the long-term goal of the company is one of the important corporate decision makings. Also, chosen business strategy have significant influence on the current and future performance and financial status of a firm (Yi \& Park 2014).

Exploiting classification of Porter (1985), we divide our sample into firms with product differentiation strategy and firms with cost leadership strategy. Product differentiation strategy is a strategy to obtain a higher price by offering a product that is differentiated and competitive products to the customers. When a firm uses product differentiation strategy, it should find the product feature that attracts its customers. Then, it must be able to provide differentiated products those reflect the attractive characteristics. The key factors for the success of product differentiation strategy are continuous R\&D investments, superior technology, and manufacturing and marketing capabilities. Cost leadership strategy is a strategy to gain a competitive advantage by supplying the goods or services at the lowest price. A thorough cost control strategy is necessary for the success of this strategy. Firms using cost leadership strategy put their efforts on increasing the production efficiency and exploiting economies of scale in order to achieve cost advantage (Porter, 1985). 
In general, firms with product differentiation strategy mostly relies on the technology. Therefore, $R \& D$ investments are important and critical to the survival and growth of product differentiation firms. R\&D of product differentiation firms develops new products or improves the quality and specification of existing products and designs. Product differentiation strategy is to pursue future growth through innovation in products and firm's core business activities. Thus, R\&D in product differentiation firms play very important role (Biggadike, 1979). Product differentiation firms allocate most of their resources on $R \& D$ compared with other investment projects while cost leadership firms are not likely to allocate their main resources on $\mathrm{R} \& \mathrm{D}$. For this reason, the $\mathrm{R} \& \mathrm{D}$ activities are core business activity of product differentiation firms (Miller, 1987).

Previous studies show conflicting findings on the relation between R\&D investment and firm performance. Many of them argue that $R \& D$ investments are positively related with firm value (Cho \& Chung, 2001; Chung, Jeon, \& Kim, 2003; Sougiannis, 1994). However, some studies report R\&D investments are negatively related with firm value (J. Chung \& Park, 2004; Kwon \& Lee, 2004; Lee \& Kim, 2002). Lev and Zarowin (1999) argues change of R\&D investment makes big difference on the change of future earnings. More specifically, they classify the nature of R\&D into two types: maintaining current competitive position and changing current competitive position. If a firm exploit R\&D investment as a tool for the changing current competitive position, one can expect the uncertainty surrounding its R\&D investments will be increasing. In lieu of this perspective, regardless of the nature of R\&D classified by Lev and Zarowin (1999), our study examines the effect of business strategy on the relation between R\&D investments and firm performance.

We classify business strategy into two types, namely, product differentiation strategy and cost leadership strategy. In order to compose empirical measure for business strategy, we cluster three variables: R\&D intensity, profit margin, and asset turnover (Jermias, 2008; Singh \& Agarwal, 2002). We cluster those three variables with standardized threeyear moving average value. This is because business strategies reflect relatively long-term decision makings rather than a single-year decision makings (Yi \& Park, 2014).

The empirical results are as follows. First, we find insignificant effect of business strategy on the relation between R\&D and earnings persistence. Second, in case of product differentiation firms, we find positive and significant effect of business strategy on the relation between $R \& D$ and consecutive earnings growth up to three years. However, we could not find any significant effect of choosing cost leadership strategy on the relation between R\&D and earnings growth. It suggests that choosing product differentiation strategy strengthens the relation between R\&D and earnings growth in the consecutive years. Third, choosing product differentiation strategy increases the relation between R\&D and firm value while choosing cost leadership strategy does not significantly affect the relation between R\&D and firm value.

This study has several contributions. First, this paper presents empirical evidence to support that choosing a business strategy has influence on the relation between R\&D and firm performance. Second, we believe the results of this study are useful to practitioners when they are making R\&D-related decisions based on their business planning. Also, this study provides useful empirical results to financial analysts and accounting academics when they are analyzing profitability and firm value. The remainder of this paper is organized as follows. Chapter 2 reviews the previous studies and Chapter 3 develops hypotheses, designs empirical models, and shows sample selection procedures. Chapter 4 reports the empirical results and Chapter 5 provides conclusions.

\section{LITERATURE REVIEW}

Looking at the relation between $R \& D$ and the firm performance, $R \& D$ investments can be seen as having replaced the flow and capital investment or capital expenditure for the commercial production for the production of certain products before the start of commercial production of capital spending activity stream (Chung \& Park, 2014). Results from prior studies examine the relation between R\&D and firm performances are mixed. Many of prior studies argue that R\&D increases both financial performance and firm value. Sougiannis (1994) argues that investments in intangibles increase the value of tangibles due to the indirect effects. That is, net present value for intangible investments is higher than the net present value of tangible investments, and therefore, intangible investments have more positive effect on firm value than tangible investments do. Paek (2003) compares the relation between R\&D and stock price across industry sectors. More specifically, he classifies the whole industry into two groups: information technology sector 
and traditional manufacturing sector. He reports, $R \& D$ and advertisement expense of information technology sector are positively related with stock price while he finds no significant relation between intangible investments and stock price in the traditional manufacturing sector. These studies argue that R\&D is positive related with financial performance and stock price.

However, other studies document the negative relation between R\&D and firm performance. Chung and Park (2004) study the relation between $R \& D$ and firm value. More specifically, they identify ventures and non-ventures among the KOSDAQ listed firms. They find, the relation between ordinary $R \& D$ and firm value is positive and significant. Also, the value relevance of ordinary R\&D differs between venture and non-venture firms. However, the relation between non-ordinary and firm value is negative and they could not find the difference of value relevance of nonordinary R\&D between venture and non-venture firms. Oh (2005) examines the relation between R\&D and stock price of KOSDAQ listed firms, period 1999 to 2003. He finds stock price is negatively related with R\&D of previous year while stock price is positively related with $R \& D$ of year $t-2$ and $t-3$.

Next, looking at the prior literature document the relation between business strategy and firm performance, Selling and Stickney (1989) analyzes the cross-sectional and time-series patterns of return on asset. Specifically, they argue that firm life-cycle and operating leverage are determinants of return on asset. Nissim and Penman (2001) renders financial statement analysis in order to find leading indicators of financial ratios which determine the future cash flow. In part, they find capital margin have mean-reversion property. Fairfield and Yohn (2001) argues that dividing return on asset into profit margin and asset turnover does not seem to provide additional insights. However, they argue that dividing change of return on asset into change of profit margin and change of asset turnover enhances predictability of firm performance. Oh (2012) tests whether strategy and timing of investment influence firm performance, and whether propensity of R\&D capitalization policy differs across business strategies. She finds that R\&D of product differentiation firms have propensity to influence on the future performance rather than on the current performance. Additionally, she reports that both product differentiation firms and cost leadership firms prefer not to adapt R\&D capitalization policy while adapting R\&D capitalization policy does not influence on firm performance.

\section{RESEARCH DESIGN}

\subsection{Hypotheses}

Product differentiation strategy is a strategy to obtain a higher price by offering a product that is differentiated and competitive products to the customers. When a firm uses product differentiation strategy, it should find the product feature that attracts its customers. Then, it must be able to provide differentiated products those reflect the attractive characteristics. The key factors for the success of product differentiation strategy are continuous R\&D investments, superior technology, and manufacturing and marketing capabilities.

Cost leadership strategy is a strategy to gain a competitive advantage by supplying the goods or services at the lowest price. A thorough cost control strategy is necessary for the success of this strategy. Firms using cost leadership strategy put their efforts on increasing the production efficiency and exploiting economies of scale in order to achieve cost advantage.

In general, firms with product differentiation strategy mostly relies on the technology. Therefore, R\&D investments are important and critical to the survival and growth of product differentiation firms. R\&D of product differentiation firms develops new products or improves the quality and specification of existing products and designs. Product differentiation strategy is to pursue future growth through innovation in products and firm's core business activities. Thus, R\&D in product differentiation firms play very important role (Biggadike, 1979). Product differentiation firms allocate most of their resources on R\&D compared with other investment projects while cost leadership firms are not likely to allocate their main resources on $R \& D$. For this reason, the $R \& D$ activities are core business activity of product differentiation firms (Miller, 1987).

Therefore, we expect $R \& D$ of product differentiation firms are more likely to boost firm performance than $R \& D$ of cost leadership firms. Based on the expectations, we set our research hypotheses as follows: 
Hypothesis 1: The effect of R\&D on earnings persistence differs across business strategies

Hypothesis 2: The effect of R\&D on earnings growth differs across business strategies

Hypothesis 3: The effect of R\&D on firm value differs across business strategies

\subsection{Research Models}

\subsubsection{Classification of Business Strategies}

Typically, many researchers use the framework of Porter (1985)'s classification which introduces product differentiation strategy and cost leadership strategy. Consistent with prior literature, we assume a firm can choose either product differentiation strategy or cost leadership strategy. Then, we render cluster analysis with three variables closely related to the characteristics of each business strategy, namely, R\&D intensity, asset turnover, and profit margin (Jermias, 2008; Singh \& Agarwal, 2002). In addition, the variables exploited in cluster analysis are measured by three-year moving average and standardized because business strategy is determined in the long term rather than short-term (Yi \& Park, 2014).

The rationale behind choosing three variables are so follows. First, $R \& D$ intensity is a very important factor in product differentiation. Bring innovation through research and development of products or services secure price premium. Second, asset turnover, in other words, asset utilization efficiency, is one of the most important factor which constitutes cost leadership strategy. The goal of cost leadership strategy firms is to deliver the goods at a lower price in pursuit of economies of scale or production efficiency. If this is the case, low price and efficient production technology is competitive advantage of cost leadership firms. Next, profit margin refers to the ability of companies to charge extra price for products or services to the customers. Lynn (1994) argues that choosing product differentiation strategy means firms provides unique products and services. It distinguishes product differentiation firms from cost leadership firms. Table 1 shows the characteristics of three variables for each strategy. For example, firms choosing product differentiation strategy are likely to accompany higher R\&D intensity and gross profit margin than cost leadership firms. On the contrary, cost leadership firms have propensity to exhibit higher asset turnover and lower gross profit margin and R\&D intensity than product differentiation firms (Jermias, 2008; Yi \& Park, 2014).

Table 1. Classification of Business Strategy

\begin{tabular}{l|c|c}
\hline \multicolumn{1}{c|}{ Strategy } & Product Differentiation & Cost Leadership Strategy \\
\hline Asset turnover & Low & High \\
\hline Gross profit margin & High & Low \\
\hline R \& D intensity & High & Low \\
\hline
\end{tabular}

\subsubsection{The Effect of Strategy on the Relation between $R \& D$ and Earnings Persistence}

In this study, we estimate following regression model to examine whether there are differences of R\&D-performance relation across business strategies. We construct model (1) to test hypothesis 1 as follows:

$$
\begin{aligned}
& \text { ROA }_{t+1}=\beta_{0}+\beta_{1} \text { ROA }_{t}+\beta_{2} \text { RNDratio }_{t}+\beta_{3} \text { ROA }_{t} * \text { RNDratio }_{t}+\beta_{4} \text { STRATEGY }_{t}+\beta_{5} \text { STRATEGY }_{t} * \\
& \text { ROA }_{t}+\beta_{6} \text { STRATEGY }_{t} * \text { RNDratio }_{t}+\beta_{7} \text { STRATEGY }_{t} * \text { ROA }_{t} * \text { RNDratio }_{t}+\beta_{8} \text { SIZE E }_{t}+\beta_{9} \text { LEV }_{t}+ \\
& \beta_{10} \text { Inv }_{-} \text {PPE }_{t}+\beta_{11} \text { Cash }_{t}+\text { Year Dummies }
\end{aligned}
$$

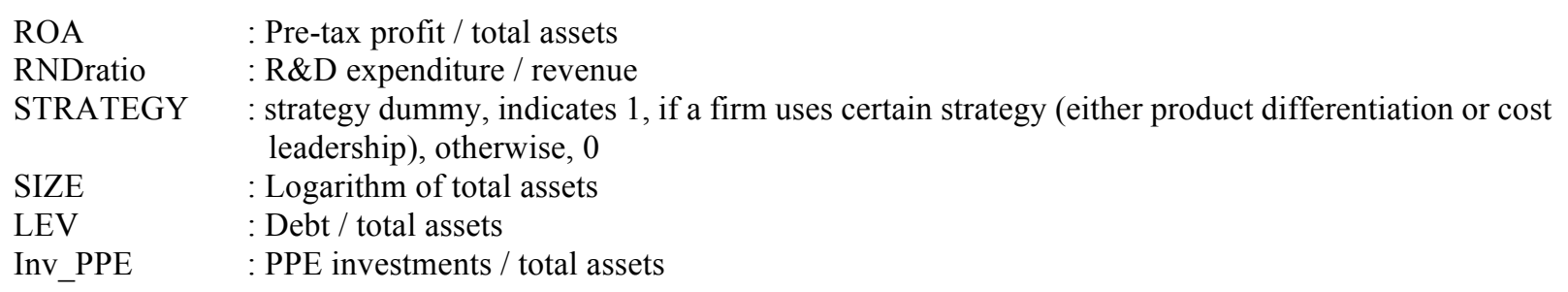




$$
\begin{array}{ll}
\text { Cash } & : \text { Cash and cash equivalents / total assets } \\
\text { YearDummies } & \text { : Year dummy }
\end{array}
$$

We modify earnings persistence model proposed by Dechow and Dichev (2002) to test the difference of the relation between R\&D and earnings persistence across business strategies. We expect positive and significant parameter estimates on beta1, which explains earnings persistence from period t to period $\mathrm{t}+1$.

The dependent variable in the model (1) is ROA of period $t+1$, and explanatory variables are ROA of period $t$, RNDratio, and STRATEGY. STRATEGY is dummy variable indicates 1, if a firm uses certain strategy (product differentiation or cost leadership), estimated by clustering R\&D intensity, asset turnover, and profit margin. If there are differences in relation between $R \& D$ and earnings persistence across business strategy, estimated coefficient for STRATEGY*ROA*RNDratio will be significant.

Control variables of the estimation model are as follows: SIZE, measured by natural logarithm of the total assets, controls for size effect, information environment surrounding the firm, and other omitted variables. LEV, total debt divided by total assets, controls for financial stability. Also, ceteris paribus, firms with higher debt ratio are likely to experience lower future profitability (Beaver, Kettler, \& Scholes, 1970). Inv_PPE refers to investments in plant, property, and equipment, and controls for the relation between R\&D project and subsequent (or contemporaneous) PPE investments. CASH, cash and cash equivalents divided by total assets, controls for the liquidity of the firm. Lastly, we include YearDummies, vector for year fixed effects, in the estimation model (1).

\subsubsection{The Effect of Strategy on the Relation between R\&D and Profit Growth}

To test whether the relation between $R \& D$ and profit growth differ across business strategies, we construct the following estimation model.

$$
\begin{aligned}
& \text { EarningsGrowth } h_{t+1-3}=\beta_{0}+\beta_{1} \text { ROA }_{t}+\beta_{2} \text { RNDratio }_{t}+\beta_{3} \text { STRATEGY }_{t}+\beta_{4} \text { STRATEGY }_{t} * \text { ROA }_{t}+ \\
& \beta_{5} \text { STRATEGY }_{t} * R N D \text { atio } \\
& +\beta_{6} \text { SIZE }_{t}+\beta_{7} L E V_{t}+\beta_{8} \text { Inv }_{-} P P E_{t}+\beta_{9} \text { CASH }_{t}+\text { Year Dummies }
\end{aligned}
$$

We expand the estimation model of Lev and Nissim (2004) to examine the effect of business strategy on the relation between $R \& D$ and earnings growth up to $t+1$. The dependent variable of model (2) is earnings growth of period $t+1$. Our variable of interest is STRATEGY*RNDratio. If a certain business strategy moderates the relation between R\&D and earnings growth, the estimated coefficient for STRATEGY*RNDratio will be significant.

\subsubsection{The Effect of Strategy on the Relation between R\&D and Firm Value}

To test whether business strategy affect the relation between R\&D and firm value (hypothesis 3 ), we estimate the following model.

$$
\begin{aligned}
& \text { Tobin }_{t+t=1}=\beta_{0}+\beta_{1} \text { ROA }_{t}+\beta_{2} \text { RNDratio }_{t}+\beta_{3} \text { STRATEGY }_{t}+\beta_{4} \text { STRATEGY }_{t} * \text { RNDratio }_{t}+ \\
& \beta_{6} L E V_{t}+\beta_{7} I n v_{-} P P E_{t}+\beta_{8} C A S H_{t}+\text { Year Dummies }
\end{aligned}
$$

In order to examine the effect of business strategy on the relation between R\&D and firm value, first of all, we calculate the proxy for the firm value, Tobin's Q, defined as market value of firm's net asset and long-term liability divided by total assets (Morck, Shleifer, \& Vishny, 1988). The variable of our interest is STRATEGY*RNDratio. If a certain strategy, product differentiation or cost leadership, makes significant difference on the relation between R\&D and firm value, the parameter estimate on the STRATEGY*RNDratio will be significant. 


\subsection{Sample Selection Procedures}

Our sample consists of Korea Stock Exchange (KOSPI) and Korean Securities Dealers Automated Quotations (KOSDAQ) listed and non-financial sector firm-year observations period 2002 to 2011 . We obtain financial data from TS2000 and FnGuide database. Specifically, our sampling procedures as follows:

(1) We collect all non-financial firms listed in KOSPI and KOSDAQ, fiscal year ends in December.

(2) Company financial data can be extracted using the TS2000 provided by the Korea Listed Companies Association and the DataGuide Pro 5.0 provided by Maekyung FnGuide.

(3) Firms with financial time-series since 2002

(4) Firms with nonzero R\&D expenditure

\subsection{Industry Distribution}

Table 2 reports the industry distribution of our final sample. We classify industries in accordance with the $9^{\text {th }}$ Korea Standard Industrial Classification Code (KSIC). Our final sample consists of 9,767 firm-year observations. Among the whole sample, the portion of computers and electronics industry is $16.41 \%$, other machinery and equipment industry accounts for $9.8 \%$, chemical manufacturing $6.58 \%$, autos $6.26 \%$, and pharmaceutical manufacturing $6.01 \%$ respectively.

Table 2. Industry Distributions

\begin{tabular}{|c|c|c|}
\hline Industry & Sample n & Ratio(\%) \\
\hline Autos & 611 & 6.26 \\
\hline Basic metal products & 486 & 4.98 \\
\hline Chemicals & 643 & 6.58 \\
\hline Computers and electronics & 1,603 & 16.41 \\
\hline Constructions & 392 & 4.01 \\
\hline Electronic equipments & 326 & 3.34 \\
\hline Fabricated metal products & 217 & 2.22 \\
\hline Food products & 513 & 5.25 \\
\hline Information and communications & 369 & 3.78 \\
\hline Medical, precision, and opticals & 195 & 2 \\
\hline Non-metalic minerals & 237 & 2.43 \\
\hline Other machinery and equipment & 957 & 9.8 \\
\hline Other manufacturing & 526 & 5.39 \\
\hline Pharmceuticals & 587 & 6.01 \\
\hline Publishing activities & 450 & 4.61 \\
\hline Rubber and plastics & 262 & 2.68 \\
\hline Science and business services & 346 & 3.54 \\
\hline Textiles and apparels & 326 & 3.34 \\
\hline Wholesale and retail trade & 498 & 5.1 \\
\hline Wood products & 223 & 2.28 \\
\hline Total & 9,767 & $100 \%$ \\
\hline
\end{tabular}

\section{EMPIRICAL RESULTS}

\subsection{Descriptive Statistics}

We report summary statistics of variables used in this paper reported in Table 3 . The ROA of year $t$ and $t+1$ are approximately $3.7 \%$ and $3.5 \%$ respectively. In case of our proxy for firm value, Tobin's Q, exhibits averagely 1.568 (year $\mathrm{t}$ ) and 1.694 (year $\mathrm{t}+1$ ). Average firms spend 3.5\% of total sales for R\&D expenditure. With respect to underlying characteristics, total asset of average firm is 18.744 , equivalent to 138.1 billion Korean Won. The average debt ratio is $42.3 \%$ (total debt/total assets) and average ratio of plant, property, and equipment to total assets is $44.1 \%$. Lastly, 
sample firms tend to maintain cash to total assets at $7.6 \%$ on average. Most of descriptive statistics are consistent with economic substances.

Table 3. Descriptive Statistics $(n=9,767)$

\begin{tabular}{l|c|c|c|c|c|c|r|r}
\hline \multicolumn{1}{c}{ Variables } & Mean & Std. & $\mathbf{1 0 \%}$ & $\mathbf{2 5 \%}$ & Median & $\mathbf{7 5 \%}$ & $\mathbf{9 0 \%}$ \\
\hline ROAt & 0.037 & 0.142 & -0.099 & 0.004 & 0.047 & 0.103 & 0.171 \\
\hline ROAt+1 & 0.035 & 0.119 & -0.094 & 0.002 & 0.042 & 0.095 & 0.159 \\
\hline TobinQt & 1.568 & 1.762 & 0.054 & 0.201 & 0.704 & 2.276 & 8.631 \\
\hline TobinQt+1 & 1.694 & 1.856 & 0.064 & 0.234 & 0.797 & 2.598 & 9.798 \\
\hline RNDratio & 0.035 & 0.063 & 0.001 & 0.004 & 0.014 & 0.037 & 0.084 \\
\hline SIZE & 18.744 & 1.473 & 17.195 & 17.735 & 18.429 & 19.418 & 20.833 \\
\hline LEV & 0.423 & 0.203 & 0.151 & 0.265 & 0.423 & 0.568 & 0.684 \\
\hline Inv_PPE & 0.441 & 0.399 & 0.095 & 0.223 & 0.38 & 0.57 & 0.769 \\
\hline CASH & 0.076 & 0.088 & 0.006 & 0.018 & 0.048 & 0.101 & 0.183 \\
\hline
\end{tabular}

\subsection{Correlation Matrix}

Table 4 reports correlation coefficients between the variables used in the hypotheses tests. Correlation coefficients between $\operatorname{ROA}(t)$ and TobinQ $(t)$ and $\operatorname{TobinQ}(t+1)$ are negative and significant. We find negative correlation between RNDratio and ROA while RNDratio is positively correlated with TobinQ. Among the control variables, LEV is negatively correlated with $\operatorname{ROA}(t)$ and $\operatorname{ROA}(t+1)$ while other control variables (SIZE, Inv_PPE, and CASH) are positively correlated with $\operatorname{ROA}(\mathrm{t})$ and $\mathrm{ROA}(\mathrm{t}+1)$. With respect to firm value, SIZE and Inv_PPE are positively correlated with TobinQ(t) and TobinQ $(\mathrm{t}+1)$ while CASH has positive correlation with TobinQ.

Table 4. Correlation Matrix ( $\mathrm{n}=9,767)$

\begin{tabular}{l|c|c|c|c|c|c|c|c|c}
\hline & ROAt & ROAt+1 & TobinQt & TobinQt+1 & RNDratio & SIZE & LEV & Inv_PPE & CASH \\
\hline ROA(t) & & $0.631^{* * *}$ & $-0.102^{* * *}$ & $-0.101^{* * *}$ & $-0.061^{* * *}$ & $0.169^{* * *}$ & $-0.224^{* * *}$ & $0.032^{* * *}$ & $0.242^{* * *}$ \\
\hline ROA(t+1) & $0.630^{* * *}$ & & $-0.075^{* * *}$ & $-0.073^{* * *}$ & $-0.056^{* *}$ & $0.141^{* * *}$ & $-0.191^{* * *}$ & $0.018^{*}$ & $0.186^{* * *}$ \\
\hline TobinQ(t) & $-0.117^{* * *}$ & $-0.088^{* * *}$ & & $0.942^{* * *}$ & $0.077^{* * *}$ & $-0.494^{* * *}$ & $-0.082^{* * *}$ & $-0.167^{* * *}$ & $0.034^{* * *}$ \\
\hline TobinQ(t+1) & $-0.107^{* * *}$ & $-0.076^{* * *}$ & $0.932^{* * *}$ & & $0.079^{* * *}$ & $-0.507^{* * *}$ & $-0.088^{* * *}$ & $-0.173^{* * *}$ & $0.041^{* * *}$ \\
\hline RNDratio & $-0.170^{* * *}$ & $-0.176^{* * *}$ & $0.047^{* * *}$ & $0.040^{* * *}$ & & $-0.308^{* * *}$ & $-0.267^{* * *}$ & $-0.220^{* * *}$ & $0.163^{* * *}$ \\
\hline SIZE & $0.197^{* * *}$ & $0.177^{* * *}$ & $-0.162^{* * *}$ & $-0.165^{* * *}$ & $-0.189^{* * *}$ & & $0.239^{* * *}$ & $0.358^{* * *}$ & $-0.154^{* * *}$ \\
\hline LEV & $-0.155^{* * *}$ & $-0.161^{* * *}$ & 0.01 & 0.006 & $-0.222^{* * *}$ & $0.233^{* * *}$ & & $0.211^{* * *}$ & $-0.237^{* * *}$ \\
\hline Inv_PPE & $0.048^{* * *}$ & $0.044^{* * *}$ & $-0.042^{* * *}$ & $-0.039^{* * *}$ & $-0.103^{* * *}$ & $0.281^{* * *}$ & $0.106^{* * *}$ & & $-0.272^{* * *}$ \\
\hline CASH & $0.135^{* * *}$ & $0.115^{* * *}$ & $0.022^{* *}$ & $0.028^{* * *}$ & $0.078^{* * *}$ & $-0.152^{* *}$ & $-0.179^{* * *}$ & $-0.168^{* * *}$ & \\
\hline
\end{tabular}

Lower-left of diagonal presents Pearson correlation coefficients and upper-right of diagonal presents Spearman correlation coefficients. $* / * * / * * *$ represents statistically significant at level $10 \% / 5 \% / 1 \%$ respectively. For variable definitions, see description for Model (1) in Section 3.2.2

\subsection{Regression Results}

\subsubsection{Testing Results for $\mathrm{H} 1$}

Table 5 presents testing results for hypothesis 1 . According to the regression results, we find no significant effects of STRATEGY on the relation between R\&D and earnings persistence. More specifically, the estimated regression coefficient on our variable of interest, STRATEGY*ROA*RNDratio, is negative and not significant in both strategies. In case of product differentiation firms (STRATEGY = Product differentiation), estimated coefficient for STRATEGY *ROA*RNDratio is $-0.339(\mathrm{t}=-0.93)$. Likewise, coefficient for STRATEGY*ROA*RNDratio is still negative and insignificant (beta $=-0.484 ; \mathrm{t}=-0.99$ ) when we set our STRATEGY dummy indicate 1 , when the corresponding observation exhibits cost leadership strategy. These results suggest that both product differentiation and cost leadership strategy do not seem to influence on the relation between R\&D and earnings persistence. 
Table 5 . Testing Results for $\mathrm{H} 1(\mathrm{n}=9,767)$

\begin{tabular}{|c|c|c|c|c|}
\hline \multicolumn{5}{|l|}{ Dependent variable $=$ ROA $t+1$} \\
\hline \multirow{2}{*}{ Variables } & \multicolumn{2}{|c|}{ (1) STRATEGY = Product differentiation } & \multicolumn{2}{|c|}{ (2) STRATEGY = Cost leadership } \\
\hline & PE & $\mathbf{t}$ & PE & $\mathbf{t}$ \\
\hline Intercept & $-0.083^{* * *}$ & -6.38 & $-0.084^{* * *}$ & -6.48 \\
\hline $\mathrm{ROA}$ & $0.438^{* * *}$ & 52.7 & $0.457^{* * *}$ & 52.76 \\
\hline RNDratio & $-0.153^{* * *}$ & -7.45 & $-0.117^{* * *}$ & -7.11 \\
\hline ROA*RNDratio & $0.632^{* * *}$ & 7.7 & $0.674^{* * *}$ & 9.19 \\
\hline STRATEGY & 0.003 & 0.83 & 0.003 & 0.94 \\
\hline STRATEGY*ROA & 0.036 & 1.26 & -0.093 & -3.96 \\
\hline STRATEGY*RNDratio & $0.104^{* *}$ & 2.31 & $-0.189^{* *}$ & -2.14 \\
\hline STRATEGY*ROA*RNDratio & -0.339 & -0.93 & -0.484 & -0.99 \\
\hline SIZE & $0.007^{* * *}$ & 9.65 & $0.007^{* * *}$ & 10 \\
\hline LEV & $-0.057^{* * *}$ & -11.3 & $-0.060^{* * *}$ & -11.94 \\
\hline Inv PPE & -0.002 & -0.63 & -0.002 & -0.68 \\
\hline $\mathrm{CA} \overline{\mathrm{S}} \mathrm{H}$ & $0.059^{* * *}$ & 5.38 & $0.053^{* * *}$ & 4.8 \\
\hline Fixed effects & \multicolumn{2}{|c|}{ Year } & \multicolumn{2}{|c|}{ Year } \\
\hline Adj. R2 & \multicolumn{2}{|c|}{0.42} & \multicolumn{2}{|c|}{0.42} \\
\hline
\end{tabular}

*/**/*** represents statistically significant at level 10\%/5\%/1\% respectively. For variable definitions, see description for Model (1) in Section 3.2.2

\subsubsection{Testing Results for $\mathrm{H} 2$}

The timing that $R \& D$ investment become feasible is different across circumstances. More specifically, the patterns of the relation between $R \& D$ and earnings growth of consecutive years are depend on business strategy. In our analysis, we examine the relation between $R \& D$ and earnings growth at $t+1, t+2$, and $t+3$ respectively.

Table 6, Table 7, and Table 8 reports testing results for H2. Table 6 shows regression results when dependent variable of the estimation model is earnings growth up to year $t+1$, Table 7 for $t+2$, and Table 8 for up to $t+3$, respectively. Our variable of interest, estimated coefficients on STRATEGY*RNDratio are positive and significant across tables. In addition, estimated coefficients for STRATEGY*RNDratio become greater and more significant when we extend our research window. For example, Column 1 in Table 6, the estimated coefficient on the variable of interest is 0.13 $(t=2.23)$ when the dependent variable of the regression model is earnings growth up to $t+1$. However, estimated coefficient is $0.145(t=2.43)$ and $0.169(t=2.73)$ when the dependent variables are earnings growth up to $t+2$ and $t+3$ respectively. It suggests that product differentiation strategy contributes to strengthen the relation between R\&D investments and earnings growth in the consecutive years. On the contrary, $R \& D$ of cost leadership firms do not seem to significantly strengthen the relation between $R \& D$ and future earnings growth. In sum, these results indicate that R\&D are more important and have greater impacts on future performance for product differentiation firms than for cost leadership firms

Table 6. Testing Results for $\mathrm{H} 2(\mathrm{n}=9,767)$

\begin{tabular}{|c|c|c|c|c|}
\hline \multicolumn{5}{|c|}{ Dependent variable $=$ Earnings growth up to year $t+1$} \\
\hline \multirow{2}{*}{ Variables } & \multicolumn{2}{|c|}{ (1) STRATEGY = Product differentiation } & \multicolumn{2}{|c|}{ (2) STRATEGY = Cost leadership } \\
\hline & PE & $\mathbf{t}$ & PE & $\mathbf{t}$ \\
\hline Intercept & $-0.057^{* * *}$ & -2.55 & $-0.044^{*}$ & -1.95 \\
\hline ROA & $-0.461^{* * *}$ & -36.34 & $-0.514^{* * *}$ & -39.8 \\
\hline RNDratio & $-0.154^{* * *}$ & -4.99 & $-0.153^{* * *}$ & -5.62 \\
\hline STRATEGY & -0.004 & -0.76 & $-0.022^{* * *}$ & -4.65 \\
\hline STRATEGY*ROA & 0.04 & 1 & $0.383^{* * *}$ & 11.8 \\
\hline STRATEGY*RNDratio & $0.130^{* *}$ & 2.23 & 0.068 & 0.47 \\
\hline SIZE & $0.007^{* * *}$ & 5.55 & $0.006^{* * *}$ & 5.12 \\
\hline LEV & $-0.087^{* * *}$ & -9.98 & $-0.087^{* * *}$ & -10.07 \\
\hline Inv_PPE & $-0.010^{* * *}$ & -2.39 & $-0.007^{*}$ & -1.78 \\
\hline CASH & $-0.047^{* * *}$ & -2.46 & -0.027 & -1.43 \\
\hline Fixed effects & \multicolumn{2}{|c|}{ Year } & \multicolumn{2}{|c|}{ Year } \\
\hline Adj. R2 & \multicolumn{2}{|c|}{0.13} & \multicolumn{2}{|c|}{0.15} \\
\hline
\end{tabular}


Table 7. Testing Results for $\mathrm{H} 2(\mathrm{n}=9,767)$

\begin{tabular}{|c|c|c|c|c|}
\hline \multicolumn{5}{|c|}{ Dependent variable $=$ Earnings growth up to year $\mathrm{t}+2$} \\
\hline \multirow{2}{*}{ Variables } & \multicolumn{2}{|c|}{ (1) STRATEGY = Product differentiation } & \multicolumn{2}{|c|}{ (2) STRATEGY = Cost leadership } \\
\hline & $\mathbf{P E}$ & $\mathbf{t}$ & PE & $\mathbf{t}$ \\
\hline Intercept & $-0.118^{* * *}$ & -5.1 & $-0.109^{* * *}$ & -4.72 \\
\hline ROA & $-0.509^{* * *}$ & -39.19 & $-0.532^{* * *}$ & -39.95 \\
\hline RNDratio & $-0.132^{* * *}$ & -4.17 & $-0.107^{* * *}$ & -3.81 \\
\hline STRATEGY & -0.003 & -0.6 & $-0.012^{* * *}$ & -2.43 \\
\hline STRATEGY*ROA & 0.061 & 1.48 & $0.210^{* * *}$ & 6.27 \\
\hline STRATEGY*RNDratio & $0.145^{* * *}$ & 2.43 & -0.063 & -0.42 \\
\hline SIZE & $0.010^{* * *}$ & 8.3 & $0.010^{* * *}$ & 8.09 \\
\hline LEV & $-0.078^{* * *}$ & -8.68 & $-0.080^{* * *}$ & -8.97 \\
\hline Inv_PPE & $-0.015^{* * *}$ & -3.51 & $-0.013^{* * *}$ & -3.12 \\
\hline $\mathrm{CAS} \mathrm{S}$ & $-0.036^{*}$ & -1.87 & -0.026 & -1.32 \\
\hline Fixed effects & \multicolumn{2}{|c|}{ Year } & \multicolumn{2}{|c|}{ Year } \\
\hline Adj. R2 & \multicolumn{2}{|c|}{0.15} & \multicolumn{2}{|c|}{0.16} \\
\hline
\end{tabular}

Table 8. Testing Results for $\mathrm{H} 2(\mathrm{n}=9,767)$

\begin{tabular}{|c|c|c|c|c|}
\hline \multicolumn{5}{|c|}{ Dependent variable $=$ Earnings growth up to year $\mathrm{t}+3$} \\
\hline \multirow[t]{2}{*}{ Variables } & \multicolumn{2}{|c|}{ (1) STRATEGY = Product differentiation } & \multicolumn{2}{|c|}{ (2) STRATEGY = Cost leadership } \\
\hline & PE & $\mathbf{t}$ & PE & $\mathbf{t}$ \\
\hline Intercept & $-0.146^{* * *}$ & -6.1 & $-0.137^{* * *}$ & -5.71 \\
\hline ROA & $-0.544^{* * *}$ & -40.36 & $-0.559^{* * *}$ & -40.44 \\
\hline RNDratio & $-0.146^{* * *}$ & -4.43 & $-0.111^{* * *}$ & -3.82 \\
\hline STRATEGY & -0.004 & -0.75 & $-0.011^{* *}$ & -2.25 \\
\hline STRATEGY*ROA & $0.075^{*}$ & 1.75 & $0.171^{* * *}$ & 4.93 \\
\hline STRATEGY*RNDratio & $0.169 * * *$ & 2.73 & -0.111 & -0.71 \\
\hline SIZE & $0.012^{* * *}$ & 9.5 & $0.012^{* * *}$ & 9.28 \\
\hline LEV & $-0.087^{* * *}$ & -9.33 & $-0.089^{* * *}$ & -9.62 \\
\hline Inv_PPE & $-0.010^{* *}$ & -2.19 & $-0.008^{*}$ & -1.86 \\
\hline $\mathrm{CA} \overline{\mathrm{S}} \mathrm{H}$ & -0.002 & -0.09 & 0.007 & 0.35 \\
\hline Fixed effects & \multicolumn{2}{|c|}{ Year } & \multicolumn{2}{|c|}{ Year } \\
\hline Adj. R2 & \multicolumn{2}{|c|}{0.16} & \multicolumn{2}{|c|}{0.16} \\
\hline
\end{tabular}

*/**/*** represents statistically significant at level $10 \% / 5 \% / 1 \%$ respectively. For variable definitions, see description for Model (1) in Section 3.2.2

\subsubsection{Testing Results for $\mathrm{H3}$}

Table 9 documents the testing results whether specific business strategy have effect on the relation between R\&D and firm value. Panel A reports regression results when dependent variable is concurrent Tobin's Q and Panel B shows results when dependent variable is set to Tobin's Q of next fiscal year. In Column 1 of Panel A, estimated coefficient for STRATEGY*RNDratio is $25.674(\mathrm{t}=2.57)$ and $31.404(\mathrm{t}=2.82)$ in Panel B. However, we find positive and insignificant estimated coefficients on STRATEGY*RNDratio in both panels. It suggests that R\&D of product differentiation firms tend to boost firm value relative to cost leadership firms. Meanwhile, R\&D of cost leadership firms do not seem to significantly increase firm value relative to the product differentiation firms. 
Table 9. Testing Results for $\mathrm{H} 3(\mathrm{n}=9,767)$

\begin{tabular}{|c|c|c|c|c|}
\hline \multicolumn{5}{|c|}{ Panel A: Dependent variable = Tobin's Q of year t } \\
\hline \multirow[t]{2}{*}{ Variables } & \multicolumn{2}{|c|}{$\begin{array}{c}\text { (1) STRATEGY = } \\
\text { Product differentiation }\end{array}$} & \multicolumn{2}{|c|}{$\begin{array}{l}\text { (2) STRATEGY = } \\
\text { Cost leadership }\end{array}$} \\
\hline & PE & $\mathbf{t}$ & PE & $\mathbf{t}$ \\
\hline Intercept & $55.312^{* * *}$ & 14.33 & $55.520^{* * *}$ & 14.33 \\
\hline ROA & $-16.054^{* * *}$ & -7.67 & $-15.500^{* * *}$ & -7.49 \\
\hline RNDratio & -0.33 & -0.06 & 5.218 & 1.11 \\
\hline STRATEGY & $-1.996^{* * *}$ & -2.63 & -0.383 & -0.49 \\
\hline STRATEGY*RNDratio & $25.674^{* * *}$ & 2.57 & 40.719 & 1.64 \\
\hline SIZE & $-2.680^{* * *}$ & -12.86 & $-2.731^{* * *}$ & -13.17 \\
\hline LEV & $4.545^{* * *}$ & 3.05 & $5.045^{* * *}$ & 3.39 \\
\hline Inv PPE & 0.215 & 0.3 & 0.239 & 0.33 \\
\hline $\mathrm{CA} \overline{\mathrm{S}} \mathrm{H}$ & 5.204 & 1.6 & 5.235 & 1.61 \\
\hline Fixed effects & \multicolumn{2}{|c|}{ Year } & \multicolumn{2}{|c|}{ Year } \\
\hline Adj. R2 & \multicolumn{2}{|c|}{0.13} & \multicolumn{2}{|c|}{0.14} \\
\hline
\end{tabular}

Panel B: Dependent variable $=$ Tobin's $\mathrm{Q}$ of year $\mathrm{t}+1$

\begin{tabular}{|c|c|c|c|c|}
\hline \multirow[t]{2}{*}{ Variables } & \multicolumn{2}{|c|}{$\begin{array}{l}\text { (1) STRATEGY = } \\
\text { Product differentiation }\end{array}$} & \multicolumn{2}{|c|}{$\begin{array}{l}\text { (2) STRATEGY = } \\
\text { Cost leadership }\end{array}$} \\
\hline & PE & $\mathbf{t}$ & PE & $\mathbf{t}$ \\
\hline Intercept & $64.208^{* * *}$ & 14.89 & $64.630^{* * *}$ & 14.92 \\
\hline ROA & $-16.398^{* * *}$ & -7.01 & $-15.779^{* * *}$ & -6.82 \\
\hline RNDratio & -5.267 & -0.89 & 2.217 & 0.42 \\
\hline STRATEGY & $-2.236^{* * *}$ & -2.64 & -0.162 & -0.18 \\
\hline STRATEGY*RNDratio & $31.404^{* * *}$ & 2.82 & 21.852 & 0.79 \\
\hline SIZE & $-3.116^{* * *}$ & -13.38 & $-3.184^{* * *}$ & -13.74 \\
\hline LEV & $4.592^{* * *}$ & 2.76 & $5.125^{* * *}$ & 3.08 \\
\hline Inv_PPE & 0.559 & 0.7 & 0.582 & 0.72 \\
\hline CAS $\bar{S}$ & $7.412^{* *}$ & 2.04 & $7.539^{* *}$ & 2.07 \\
\hline Fixed effects & \multicolumn{2}{|c|}{ Year } & \multicolumn{2}{|c|}{ Year } \\
\hline Adj. R2 & \multicolumn{2}{|c|}{0.12} & \multicolumn{2}{|c|}{0.13} \\
\hline
\end{tabular}

\section{CONCLUSION}

R\&D expenditure is one of the most important investment for the continuous growth of a firm by improving the quality of products and services. Continuous effort for the R\&D is essential for the survival of a firm in the competitive market, implies that, choosing business strategy for achieving the long-term goal of the company is one of the important corporate decision makings. In addition, chosen business strategy have significant influence on the current and future performance and financial status of a firm (Yi \&Park 2014).

In this study, we test whether strategy of a firm, either product differentiation or cost leadership strategy, strengthens or weakens the ties between R\&D investments and firm performances. More specifically, we assume firm chooses either product differentiation of cost leadership strategy and we estimate the strategy of a firm via clustering analysis exploiting three variables, namely, R\&D intensity, asset turnover, and profit margin (Jermias, 2008; Yi, Lee, \& Hong, 2010; Yi \& Park, 2014).

Our findings are as follows. First of all, we find the effect of R\&D expenditure on earnings persistence according to the business strategy appeared to be almost insignificant. Second, the effects of R\&D expenditure on earnings growth up to three consecutive years are stronger in firms with product differentiation strategy than in firms with cost leadership strategy. These results suggest that $R \& D$ are more important and have greater impacts on future performance for product differentiation firms than for cost leadership firms. Lastly, R\&D expenditure of product differentiation firms are more closely related to the firm value than $R \& D$ expenditure of cost leadership firms. In other 
words, we find R\&D of product differentiation firms have propensity to boost firm value relative to cost leadership firms.

This paper contributes to the literature in several ways. The results of this study will be useful to practitioners, especially, business insiders, when they are making R\&D-related decisions based on their business planning. Additionally, this study provides useful ground to test the R\&D, strategy, and firm performance altogether. It will be helpful to financial analysts and academics when they are conducting research. However, the caveat of this paper is that we mostly rely on clustering analysis when we estimate and categorize a firm into a specific business strategy. Also, we only consider firm-specific factors to classify business strategy. It remains to be seen whether and how industry-specific factors affect the business strategy in the empirical settings.

\section{AUTHOR BIOGRAPHIES}

Anjung Chung is Director of Korea Printed Electronics Association. He received PhD from Hanyang University Business School in 2014. His research interests are in the areas of value relevance of intangibles and industrial strategies.

Manseek Choi is Adjunct Professor of Accounting in Hanyang University Business School. Also, he serves as Partner of Eyed Consulting Corporation. His research focuses on financial reporting, market sentiment, and financial anomalies.

\section{REFERENCES}

Beaver, W., Kettler, P., \& Scholes, M. (1970). The association between market determined and accounting determined risk measures. The Accounting Review, 45(4), 654-682.

Biggadike, R. (1979). The risky business of diversification. Harvard Business Review, 57(3), 103-111.

Cho, S., \& Chung, J. (2001). The effect of R\&D expenditures on subsequent earnings. Korean Management Review, 30(1), 289313.

Chung, A., \& Park, S. (2014). The effects of business groups on the association between R\&D intensity and firm's value. International Accounting Research, 57, 38-58.

Chung, H., Jeon, S., \& Kim, H. (2003). Different Value relevance of R\&D accounting information among industries. Korean Management Review, 32(1), 257-282.

Chung, J., \& Park, J. (2004). The impact of R\&D expenses on business value in the KOSDAQ firms. Journal of Korean Industrial Economic Association, 17(4), 1273-1289.

Dechow, P. M., \& Dichev, I. D. (2002). The quality of accruals and earnings: The role of accrual estimation errors. Accounting Review, 77, 35-59. doi: 10.2308/accr.2002.77.s-1.35

Fairfield, P. M., \& Yohn, T. L. (2001). Using asset turnover and profit margin to forecast changes in profitability. Review of Accounting Studies, 6(4), 371-385. doi: 10.1023/a:1012430513430

Jermias, J. (2008). The relative influence of competitive intensity and business strategy on the relationship between financial leverage and performance. The British Accounting Review, 40(1), 71-86. doi: http://dx.doi.org/10.1016/j.bar.2007.11.001

Kwon, H., \& Lee, H. (2004). A empirical study of the venture business' R\&D expenditure on the enterprise value. Taxation and Accounting, 15, 85-101.

Lee, D., \& Kim, M. (2002). A study on the influence of R\&D expenditure on film's growth rate -focusing on KOSDAQ market-. Korean Taxation and Accounting Journal, 3(1), 5-31.

Lev, B., \& Nissim, D. (2004). Taxable income, future earnings, and equity values. Accounting Review, 79(4), 1039-1074. doi: 10.2308/accr.2004.79.4.1039

Lev, B., \& Zarowin, P. (1999). The market valuation of R\&D expenditures. Available at SSRN: https://ssrn.com/abstract=142122.

Lynn, T. A. (1994). Learning from competition. Journal of Accountancy, 43-46.

Miller, D. (1987). The structural and environmental correlates of business strategy. Strategic Management Journal, 8(1), 55-76. doi: $10.1002 / \mathrm{smj} .4250080106$

Morck, R., Shleifer, A., \& Vishny, R. W. (1988). Management ownership and market valuation - an empirical-analysis. Journal of Financial Economics, 20(1-2), 293-315. doi: 10.1016/0304-405x(88)90048-7

Nissim, D., \& Penman, S. H. (2001). Ratio analysis and equity valuation: From research to practice. Review of Accounting Studies, 6(1), 109-154. doi: 10.1023/a:1011338221623

Oh, S. (2005). Empirical Study on the Determinants of Price in KOSDAQ Venture Firms. (PhD), Hoseo University. 
Oh, S. (2012). An Empirical Study on the relationship between Firm Performance and R\&D on the strategic orientation. Korean Accounting Journal, 21(3), 285-306.

Paek, W. (2003). Differential determinants of equity valuation between lnformation technology firms and non-banking manufacturing firms. Korean Accounting Review, 28(2), 49-74.

Porter, M. (1985). Competitive advantage: Creating and sustaining superior performance. Free Press.

Selling, T. I., \& Stickney, C. P. (1989). The effects of business environment and strategy on a firm's rate of return on assets. Financial Analysts Journal, 45(1), 43-68.

Singh, P., \& Agarwal, N. C. (2002). The effects of firm strategy on the level and structure of executive compensation. Canadian Journal of Administrative Sciences-Revue Canadienne Des Sciences De L Administration, 19(1), 42-56.

Sougiannis, T. (1994). The accounting based valuation of corporate R\&D. The Accounting Review, 69(1), 44-68.

Yi, H., Lee, S., \& Hong, S. (2010). Firm's strategy and future profitability. Korean Accounting Journal, 19(5), 67-88.

Yi, H., \& Park, S. (2014). The effects of business strategy on the association between R\&D intensity and future financial performance. Korean Accounting Journal, 23(5), 115-143. 